Sains Malaysiana 49(9)(2020): 2083-2089

http://dx.doi.org/10.17576/jsm-2020-4909-06

\title{
A Novel Chemometrics Method for HalalAuthentication of Gelatin in Food Products
}

(Kaedah Baru Kemometrik untuk Pengesahan Halal Gelatin dalam Produk Makanan)

\author{
Nurfarhana Hassan, TAhir AhmaD*, Norhidayu M. Zain \& AZMirul ASHAari
}

\begin{abstract}
The issue of halal authenticity of food and pharmaceutical products has become a concern to Muslims due to fraud and unknown sources of ingredients. The most common non-halal ingredient found in some food products and also in capsule medicine is porcine gelatin. Other sources of gelatin are bovine and fish. Numerous methods have been developed to identify between bovine, porcine, and fish gelatins due to the concern on the halal authenticity issue. Fourier transform infrared (FTIR) spectroscopy is one of the established techniques in food adulteration analysis. However, further analysis using chemometrics method is required due to the large similarities of the gelatin spectra. This paper introduces a novel chemometrics method using Fuzzy Autocatalytic Set (FACS) to determine the FTIR spectra of bovine, porcine, and fish gelatins. The unique dominant regions for these gelatins were identified. The bovine, porcine, and fish gelatins possessed different dominant region when compared to each other. The FACS method offers simple and rigorously computational procedure to differentiate bovine, porcine, and fish gelatins for halal authentication purposes.
\end{abstract}

Keywords: Chemometrics; FTIR; fuzzy graph; gelatin; halal authentication

\section{ABSTRAK}

Isu penentuan halal sesuatu produk makanan dan ubat-ubatan telah menjadi suatu kebimbangan dalam kalangan masyarakat Islam disebabkan unsur penipuan dan sumber bahan yang tidak diketahui. Isu ini timbul disebabkan oleh penipuan bahan dan sumber dalam sesuatu produk. Salah satu bahan tidak halal yang kerap ditemui di dalam produk makanan dan kapsul ubat ialah gelatin bersumberkan khinzir. Sumber gelatin yang lain ialah lembu dan ikan. Pelbagai kaedah telah diperkenalkan untuk mengenal pasti sumber gelatin antara lembu, babi dan ikan disebabkan kebimbangan terhadap isu penentuan halal. Spektroskopi penjelmaan inframerah Fourier (FTIR) merupakan salah satu kaedah yang diterima pakai bagi tujuan menganalisis bahan kandungan sesuatu makanan. Walau bagaimanapun, analisis lanjut menggunakan kaedah kemometrik adalah diperlukan disebabkan kesemua sumber gelatin menghasilkan persamaan spektra yang ketara. Lantaran itu, kajian ini memperkenalkan kaedah baru kemometrik menggunakan Set Automangkinan Kabur (FACS) untuk menentukan spektra FTIR gelatin lembu, babi dan ikan. Rantau gelombang yang unik lagi dominan bagi setiap gelatin dikenal pasti. Hasil kajian menunjukkan gelatin bersumberkan bahan daripada lembu, khizir dan ikan masing-masing menunjukkan rantau gelombang dominan yang unik dan berlainan. Kaedah FACS adalah kaedah yang mudah lagi rapi bagi membezakan gelatin yang bersumberkan bahan daripada lembu, khinzir dan ikan untuk tujuan penentuan halal.

Kata kunci: FTIR; gelatin; graf kabur; halal; kemometrik

\section{INTRODUCTION}

Halal food and beverages markets are expanded globally and their sizes are expected to increase over the coming years due to the growing demand from Muslims consumers (Tuah 2019). According to Al - Qaradawi (1994), the Quran has stated that Muslims must consume only Halal products. However, concern on halal authenticity of food and pharmaceutical products has become a rising issue due to fraud, mislabeling and unknown ingredients used in some of the products. One of the non-halal ingredients commonly found in food products is porcine gelatin. Gelatin is a protein substance that is usually used as ingredient in food products such as sweets, pastry, and dairy products (Brown 2018). It is also used in pharmaceutical industries for capsule manufacturing (Prager 2018). Gelatin is extracted from collagen of animal bone or skin. Other sources of gelatin include bovine and fish. Most major suppliers of gelatin are from non - Islamic countries, mainly European countries (Bajpai 2019). Hence, the Halal industry is concerned with the types of gelatin used in the gelatin-based product. 
The sources of gelatins can be differentiated using suitable detection methods. According to Hermanto (2013), the different sources of gelatins can be differentiated through analysis on their intramolecular structures. Numerous studies have been published to identify the sources of gelatins (Hassan et al. 2018). Some of the methods that were used to differentiate the gelatins involve biochemical, chromatography, electrophoresis, and spectroscopy techniques.

Hidaka and Liu (2003) applied pH drop method to investigate the different effect of bovine and porcine gelatins on calcium phosphate precipitation. The method was able to differentiate the gelatins based on the different induction time and peak concentrations in transformation of hydroxyapatite (HAP). Other biochemical methods used by several other researchers to differentiate the gelatins include enzyme-linked immunosorbent assay (ELISA) and polymerase chain reaction (PCR) (AlKahtani et al. 2017; Jannat et al. 2018; Venien \& Levieux 2005). However, these methods are time-consuming and some processes require high end equipment (Hassan et al. 2018). Azilawati et al. (2015) applied high performance liquid chromatography (HPLC) method to differentiate between bovine, porcine, and fish gelatins. The differences between these gelatins were able to be identified with the aid of chemometrics method called principal component analysis (PCA). Several other researchers also performed HPLC with PCA method to analyze different sources of gelatins (Nemati et al. 2004; Widyaninggar et al. 2012). Another method that is used to differentiate the gelatins is sodium dodecyl sulphatepolyacrylamide gel electrophoresis (SDS-PAGE). Nur Azira et al. $(2014,2012)$ differentiated bovine and porcine gelatin using SDS-PAGE method described by Laemmli (1970). The method was able to differentiate the gelatins based on the differences between electrophoretic polypeptides of porcine and bovine gelatin, with the aid of PCA method to classify the gelatins according to their significant molecular weight regions. On the other hand, Cebi et al. (2016) and Hashim et al. (2010) applied FTIR spectroscopy with the aid of PCA method to identify the gelatin differences by analyzing the spectra. The FTIR spectroscopy method is proven to be an effective method in food adulteration analysis (Hashim et al. 2010). However, due to large similarities of the gelatin spectra, further analysis using chemometrics method is required to differentiate the gelatin.

In this paper, a novel chemometrics method using fuzzy graph approach namely, FACS is introduced to analyze the FTIR spectra of gelatin. The FACS method was first documented in the modeling of a clinical waste incineration process (Ahmad et al. 2010). The method was also used in modeling pressurized water reactor (PWR) system for identification of depleted variables and corrosion products of the system (Ashaari et al. 2015).
In this paper, the FACS method is used along with FTIR spectroscopy to analyze the spectra of bovine, porcine, and fish gelatins. Dominant wavenumbers for each gelatin are identified and compared among them. This novel method is developed and introduced with an aim to differentiate between bovine, porcine, and fish gelatins for halal authentication purposes.

\section{MATERIALS AND METHODS}

\section{SAMPLE PREPARATION}

Three different gelatin samples of bovine (SigmaAldrich, St. Louis, MO, USA), porcine (Sigma-Aldrich, St. Louis, MO, USA), and fish (Sigma-Aldrich, St. Louis, MO, USA) were used in this study (Table 1). A total of 81 standard gelatin solutions were prepared at concentrations between $4 \%(\mathrm{w} / \mathrm{v})$ and $20 \%(\mathrm{w} / \mathrm{v})$ by dissolving the gelatin samples in distilled water at 45 ${ }^{\circ} \mathrm{C}$ for 20 min using ultrasonic bath (Fisher Scientific, Germany).

\section{FTIR MEASUREMENT}

A Spectrum Two FTIR spectrometer model (Perkin Elmer, USA) was used to obtain the gelatin spectra. The spectra of the gelatin were recorded within a range of $4000-450 \mathrm{~cm}^{-1}$ with $4 \mathrm{~cm}^{-1}$ resolution and 32 scans. A background spectrum was recorded before the gelatin samples measurement. The complete gelatin spectra were obtained by subtracting the background spectrum from the spectra of the gelatin. The results were presented in absorbance unit.

\section{FACS METHOD}

A novel chemometrics method using FACS was applied for analysis of chemical data obtained from the FTIR spectroscopy. The concept of FACS was introduced as a result of merger between fuzzy graph by Ahmad et al. (2010) and Autocatalytic Set (ACS) by Jain and Krishna (1998). Jain and Krishna (1998) first introduced the ACS concept to represent the dynamicity in a graph. The formal definition of ACS by Jain and Krishna (1998) is given as follows:

Definition 1 An ACS is a sub graph, each of whose nodes have at least one incoming link from a node belonging to the same sub graph.

Ahmad et al. (2010) introduced the concept of fuzziness into ACS and developed FACS defined as follows:

Definition 2 FACS is a sub graph each of whose nodes has at least one incoming link with membership value $\mu\left(e_{i}\right) \in(0,1], \forall e_{i} \in E$. 
The ACS graph can be represented in square matrix form called adjacency matrix, $C=\left(c_{i j}\right)$, as shown in Figure 1. The entries, $c_{i j}$ of the matrix are equal to 1 if there is a link from $j$ to $i$, and zero otherwise. For FACS graph, the entries of the matrix are represented by the fuzzy membership values.

Chemometrics analysis using the FACS was performed by modeling the FTIR spectra of gelatins in a form FACS graph. The variables and interactions between the gelatin molecule and frequency of infrared light during the FTIR analysis are represented in a form of vertices and edges. Absorbance values at specific wavelength were described as the membership values. The FACS graph of the gelatin spectra was presented in a form of matrix and System Dynamic Variable Selection (SDVSC) by Ashaari et al. (2016) was used to compute the dominant absorbance. The difference between the gelatins was observed by determining the dominant wavenumber of each gelatin spectra.

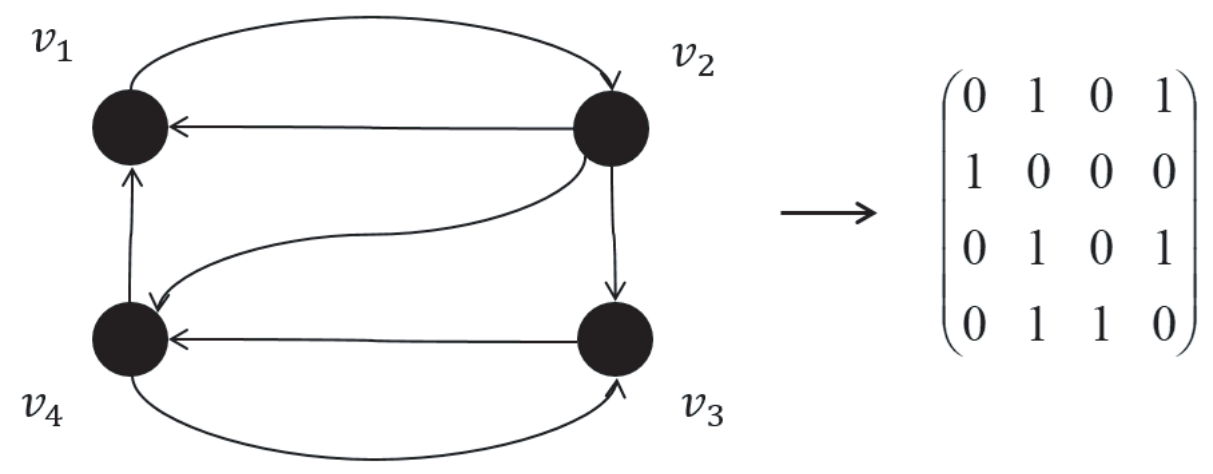

FIGURE 1. An ACS graph with 4 vertices

TABLE 1. General description of gelatin samples used in this study

\begin{tabular}{lcccc}
\hline \multicolumn{1}{c}{ Gelatin type } & Company name & Batch no. & Gelatin type & Bloom value \\
\hline Gelatin bovine skin & Sigma & SLBN8199V & Type B & $\sim 225$ \\
Gelatin porcine skin & Sigma & SLBQ9498V & Type A & $\sim 300$ \\
Gelatin cold water fish skin & Sigma & SLBQ3114V & Solid & Not stated \\
\hline
\end{tabular}

\section{RESULTS AND DISCUSSION}

FTIR ANALYSIS

The FTIR spectra of bovine, porcine, and fish gelatins are shown in Figure 2. The gelatin spectra have very similar patterns with major peaks observed at four Amide regions, 3600-3200 (Amide A), 1700-1600 (Amide I), 1560-1335 (Amide II) and 1330-670 $\mathrm{cm}^{-1}$ (Amide III).

Amide A absorption peak contains contributions from $\mathrm{N}-\mathrm{H}$ stretching vibration of hydrogen bond and $\mathrm{O}-\mathrm{H}$ stretch. The absorption band at Amide I region corresponds to the $\mathrm{C}=\mathrm{O}$ stretching of Amide group with in-phase bending of $\mathrm{N}-\mathrm{H}$ bond and minor stretching of C-N. The Amide I region is widely used for protein structural analysis due to the distinct presence of protein features at Amide I frequency (Müllertz et al. 2016). For Amide II band, the absorption arises from N-H bending and $\mathrm{C}-\mathrm{N}$ stretching. At Amide III region, the band displayed low intensity peaks due to the loss of triple helix state of collagen during its denaturation to gelatin (Muyonga et al. 2004). The absorption band at the Amide III region contains contributions from N-H bending in plane and $\mathrm{C}-\mathrm{N}$ stretching. Absorption bands at these Amide regions contain various information of 
different functional groups within its overlapping bands. The sensitivity and capability of FTIR spectroscopy method in dealing and differentiating samples with various concentrations are also studied. As a result, the spectra of each bovine, porcine, and fish gelatin displayed a well-arranged band according to its sequence of concentrations (Figure 3). This result showed that FTIR method is sensitive and capable in differentiating samples with various concentrations.

\section{FACS ANALYSIS}

The FTIR spectra of bovine, porcine, and fish gelatins showed very similar patterns and only small differences were observed in Amide II and III regions. The gelatin spectra were converted to a form of FACS graph for further analysis (Figure 4). The set of vertices, $V=\left\{v_{1}, v_{2}, v_{3}, v_{4}, \ldots, v_{n-1}, v_{n}\right\}$ represents the wavelength location while the set of edges, $E=\left\{e_{1}, e_{2}, e_{3}, e_{4}, \ldots, e_{n-1}, e_{n}\right\}$ represents the transition of the molecule to the next wavelength. Absorbance values at specific wavelength were described as the membership values. Possible presence of impurities during the chemical experiment were also included in the FACS graph. The impurities were considered as ghost elements that may cause interference during absorption of light in FTIR analysis.

The spectra at Amide II and III regions were selected for further evaluation using SDVSC. The FACS graph of Amide II and Amide III regions were converted into matrix form with dimension of $16 \times 16$ and $26 \times 26$, respectively. The absorbance values and possible presence of impurities at the selected Amide wavenumbers were described as the membership value and entries of the matrix. Each matrix was evaluated using SDVSC to find the dominant matrix. The dominant matrix obtained from the SDVSC indicates the dominant wavenumbers. The differences between the gelatins were determined based on the unique and dominant wavenumber regions of each gelatin. The result of dominant wavenumbers in Amide II region is shown in Table 2. The differences between the three gelatins were observed at dominant matrix with dimension of $6 \times 6$ for Amide II region. The result showed that bovine gelatin spectra has unique and dominant wavenumbers at 1480$1474 \mathrm{~cm}^{-1}$, while porcine and fish gelatin spectra has unique and dominant wavenumbers at 1448-1441 and 1496-1490 $\mathrm{cm}^{-1}$, respectively. For analysis on Amide III region, the dominant wavenumbers for bovine were identified from dominant matrix of $9 \times 9$ while for porcine and fish, the dominant wavenumbers were identified from dominant matrix of $8 \times 8$ and $6 \times 6$, respectively. The dominant wavenumbers that were identified from the respective matrices are $1252-1249$ and $1232-1228 \mathrm{~cm}^{-1}$ for bovine, $680-678 \mathrm{~cm}^{-1}$ for porcine, and 1303-1302 and $1283-1280 \mathrm{~cm}^{-1}$ for fish gelatin.

The unique and dominant wavenumbers for bovine, porcine, and fish gelatin spectra were successfully identified. These dominant wavenumbers indicate that there exist presence of unique and different functional groups in each bovine, fish, and non-halal porcine gelatins. In other words, each gelatin possesses its own signature and characteristics, which are different from each other.

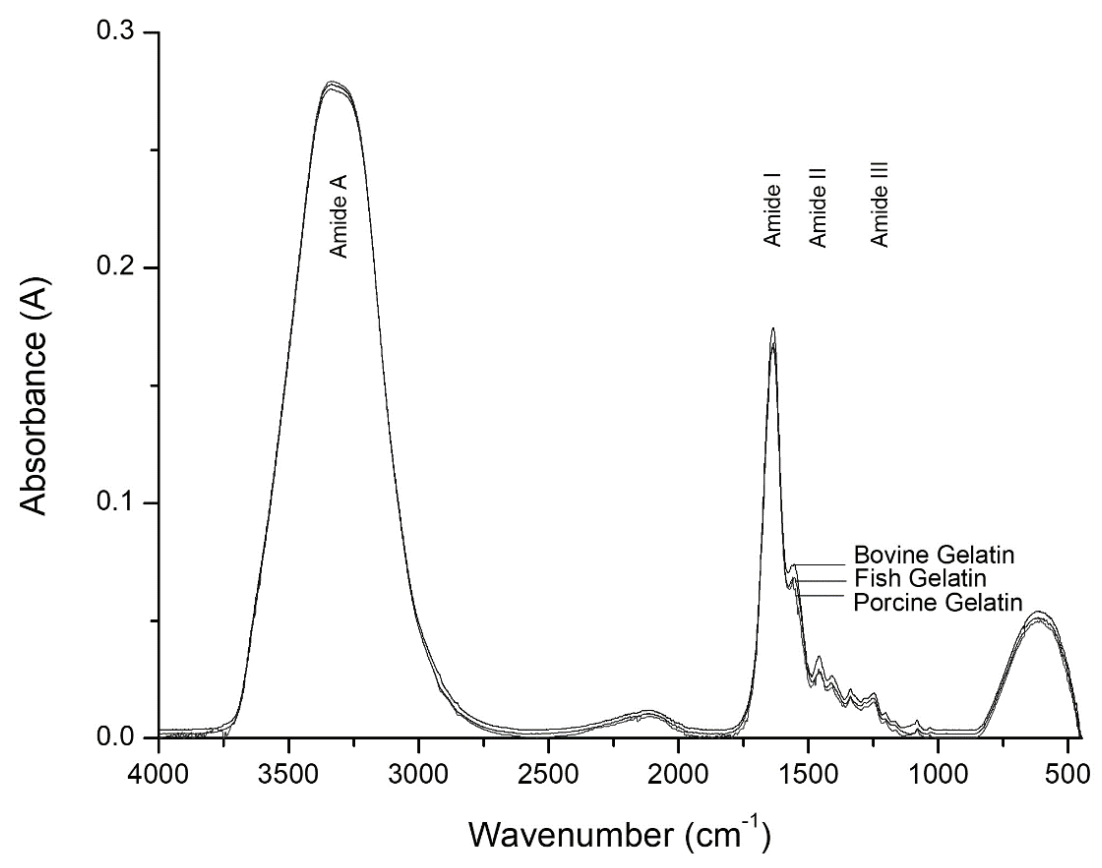

FIGURE 2. FTIR spectra of bovine, porcine, and fish gelatins 

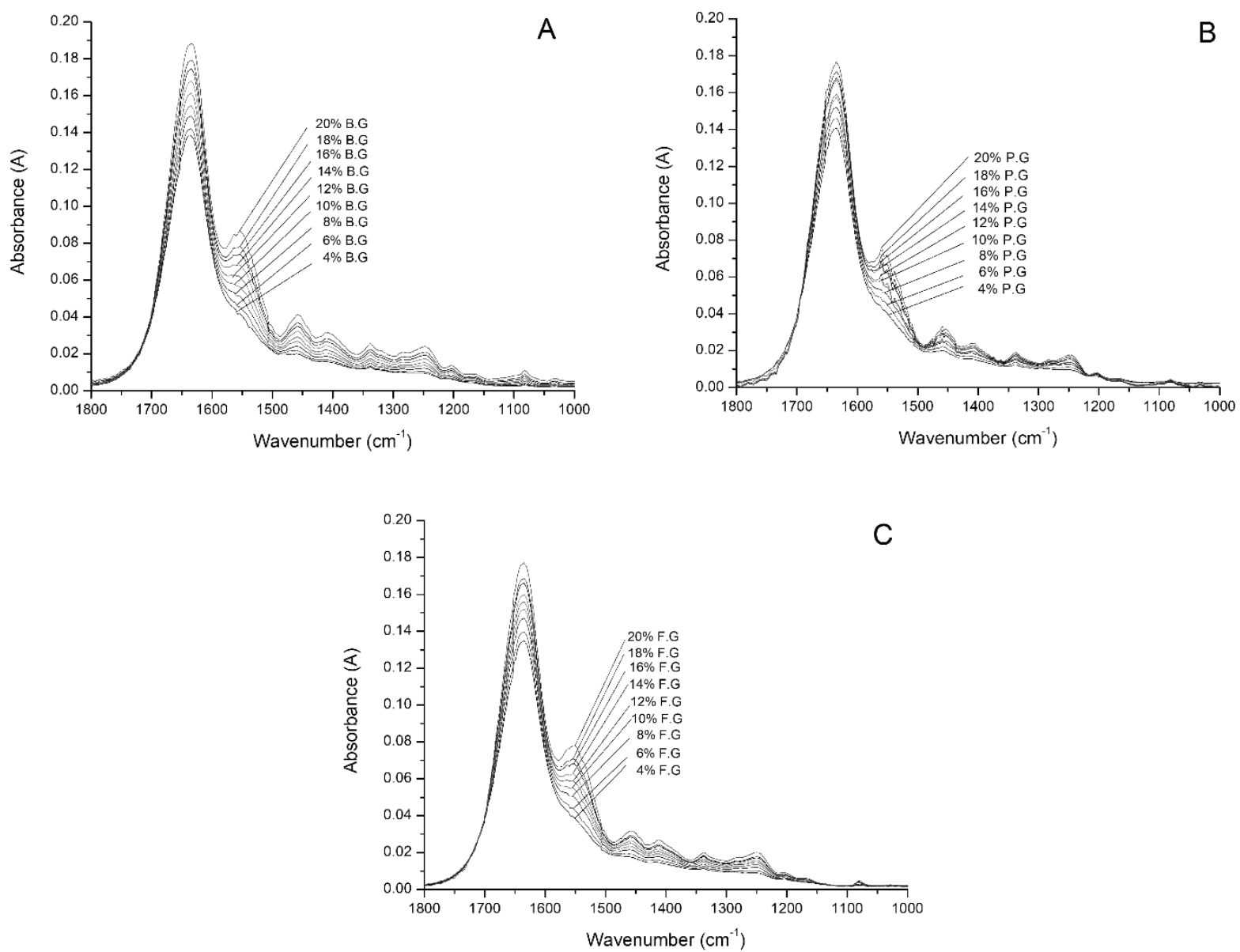

FIGURE 3. Concentration-dependent FTIR spectra of a) bovine gelatin (B.G), b) porcine gelatin (P.G) and c) fish gelatin (F.G)

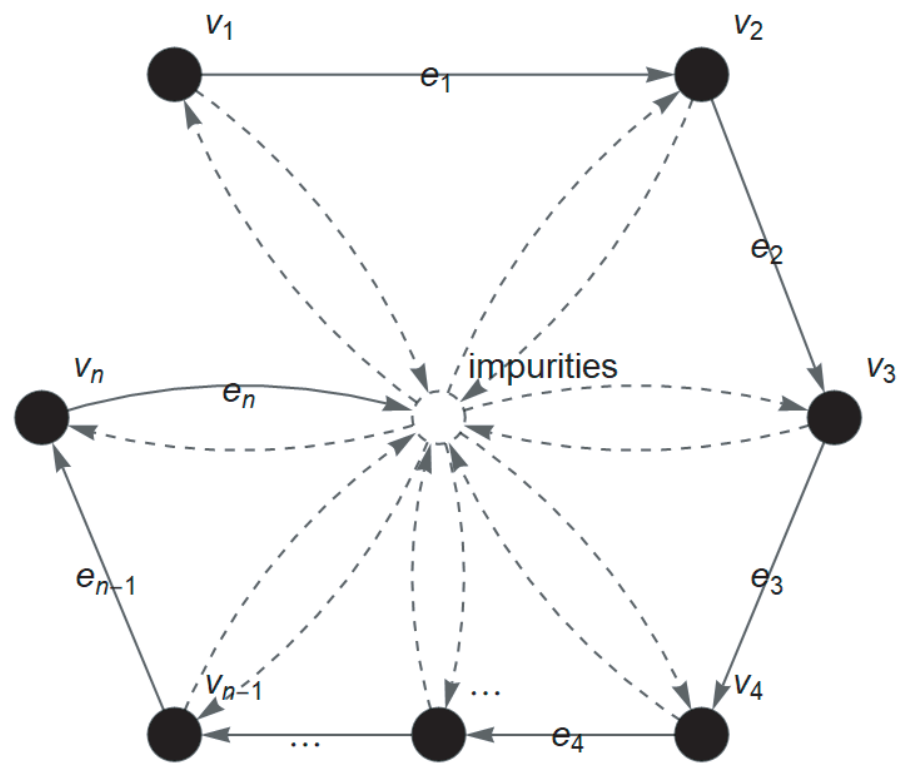

FIGURE 4. FACS graph of FTIR spectra of gelatin 
TABLE 2. Dominant output matrix with respective wavenumber regions for bovine, porcine and fish gelatin spectra at Amide II region

\begin{tabular}{|c|c|c|c|c|c|c|c|c|c|c|c|c|}
\hline \multirow{2}{*}{$\frac{\text { Gelatin }}{\text { Bovine }}$} & \multicolumn{6}{|c|}{ Output Matrix } & \multicolumn{6}{|c|}{ Wavenumber region $\left(\mathrm{cm}^{-1}\right)$} \\
\hline & 0.0569 & 0.0569 & 0.0567 & 0.0567 & 0.0565 & 0.0563 & 1560 & 1559 & 1558 & 1557 & 1555 & 1554 \\
\hline & 0.0527 & 0.0523 & 0.0520 & 0.0514 & 0.0491 & 0.0484 & 1544 & 1543 & 1542 & 1541 & 1539 & 1538 \\
\hline & 0.0420 & 0.0413 & 0.0406 & 0.0399 & 0.0387 & 0.0379 & 1528 & 1527 & 1526 & 1525 & 1523 & 1522 \\
\hline & 0.0311 & 0.0307 & 0.0303 & 0.0299 & 0.0285 & 0.0272 & 1512 & 1511 & 1510 & 1509 & 1507 & 1506 \\
\hline & 0.0234 & 0.0236 & 0.0238 & 0.0241 & 0.0247 & 0.0250 & 1480 & 1479 & 1478 & 1477 & 1475 & 1474 \\
\hline & 0.0263 & 0.0264 & 0.0265 & 0.0267 & 0.0268 & 0.0268 & 1464 & 1463 & 1462 & 1461 & 1459 & 1458 \\
\hline \multirow[t]{6}{*}{ Porcine } & 0.0586 & 0.0575 & 0.0568 & 0.0558 & 0.0548 & 0.0547 & 1560 & 1559 & 1558 & 1557 & 1554 & 1553 \\
\hline & 0.0492 & 0.0479 & 0.0466 & 0.0458 & 0.0471 & 0.0464 & 1544 & 1543 & 1542 & 1541 & 1538 & 1537 \\
\hline & 0.0413 & 0.0402 & 0.0390 & 0.0379 & 0.0356 & 0.0351 & 1528 & 1527 & 1526 & 1525 & 1522 & 1521 \\
\hline & 0.0296 & 0.0291 & 0.0288 & 0.0282 & 0.0270 & 0.0260 & 1512 & 1511 & 1510 & 1509 & 1506 & 1505 \\
\hline & 0.0251 & 0.0253 & 0.0255 & 0.0258 & 0.0254 & 0.0247 & 1464 & 1463 & 1462 & 1461 & 1458 & 1457 \\
\hline & 0.0242 & 0.0239 & 0.0236 & 0.0233 & 0.0226 & 0.0223 & 1448 & 1447 & 1446 & 1445 & 1442 & 1441 \\
\hline \multirow[t]{6}{*}{ Fish } & 0.0549 & 0.0548 & 0.0549 & 0.0551 & 0.0551 & 0.0550 & 1560 & 1559 & 1558 & 1557 & 1556 & 1554 \\
\hline & 0.0513 & 0.0506 & 0.0500 & 0.0492 & 0.0483 & 0.0474 & 1544 & 1543 & 1542 & 1541 & 1540 & 1538 \\
\hline & 0.0420 & 0.0413 & 0.0405 & 0.0398 & 0.0391 & 0.0375 & 1528 & 1527 & 1526 & 1525 & 1524 & 1522 \\
\hline & 0.0309 & 0.0302 & 0.0296 & 0.0289 & 0.0281 & 0.0260 & 1512 & 1511 & 1510 & 1509 & 1508 & 1506 \\
\hline & 0.0230 & 0.0228 & 0.0226 & 0.0224 & 0.0223 & 0.0219 & 1496 & 1495 & 1494 & 1493 & 1492 & 1490 \\
\hline & 0.0230 & 0.0232 & 0.0233 & 0.0233 & 0.0233 & 0.0233 & 1464 & 1463 & 1462 & 1461 & 1460 & 1458 \\
\hline
\end{tabular}

\section{CONCLUSION}

A novel chemometrics method using FACS to determine the FTIR spectra of bovine, porcine, and fish gelatins was successfully developed and implemented. The differences between bovine, fish, and non-halal porcine gelatin were successfully identified based on the dominant wavenumbers observed for each gelatin. The three gelatins were identified to be unique and different from each other. The unique and dominant wavenumbers indicate that each of the gelatins has unique characteristic that differentiate them from each other. The FACS method offers simple and rigorously computational procedure to differentiate bovine, porcine and fish gelatin for halal authentication purposes.

\section{ACKNOWLEDGEMENTS}

This work has been supported by UTM COE GRANT, 04G05 and MyBrainSc scholarship from the Ministry of Education, Malaysia.

\section{REFERENCES}

Ahmad, T., Baharun, S. \& Arshad, K.A. 2010. Modeling a clinical incineration process using Fuzzy Autocatalytic Set. Journal of Mathematical Chemistry 47(4): 1263-1273.

Al-Kahtani, H.A., Ismail, E.A. \& Ahmed, M.A. 2017. Pork detection in binary meat mixtures and some commercial food products using conventional and real-time PCR techniques. Food Chemistry 219: 54-60.

Al-Qaradawi, Y. 1994. The Lawful and the Prohibited in Islam (Al-Halal Wal Haram Fil Islam). Indianapolis: American Trust Publication.

Ashaari, A., Ahmad, T., Zenian, S. \& Shukor, N.A. 2016. Selection probe of EEG using dynamic graph of Autocatalytic Set (ACS). In International Conference on Soft Computing in Data Science. pp. 25-36.

Ashaari, A., Ahmad, T., Shamsuddin, M., Mohammad, W. \& Omar, N. 2015. Graph representation for secondary system of pressurized water reactor with Autocatalytic Set approach. Journal of Mathematics and Statistics 11(4): 107-112.

Azira, T.N., Che Man, Y.B., Hafidz, R.N.R.M., Aina, M.A. \& Amin, I. 2014. Use of principal component analysis for differentiation of gelatine sources based on polypeptide molecular weights. Food Chemistry 151: 286-292. 
Azira, T.N., Amin, I. \& Che Man, Y.B. 2012. Differentiation of bovine and porcine gelatins in processed products via Sodium Dodecyl Sulphate-Polyacrylamide Gel Electrophoresis (SDS-PAGE) and Principal Component Analysis (PCA) techniques. International Food Research Journal 19(3): $1175-1180$.

Azilawati, M.I., Hashim, D.M., Jamilah, B. \& Amin, I. 2015. RP-HPLC method using 6-aminoquinolyl-Nhydroxysuccinimidyl carbamate incorporated with normalization technique in principal component analysis to differentiate the bovine, porcine and fish gelatins. Food Chemistry 172: 368-376.

Bajpai, P. 2019. Biobased Polymers: Properties and Applications in Packaging. Netherlands: Elsevier.

Brown, A.C. 2018. Understanding Food: Principles and Preparation. Boston: Cengage Learning.

Cebi, N., Durak, M.Z., Toker, O.S., Sagdic, O. \& Arici, M. 2016. An evaluation of Fourier transforms infrared spectroscopy method for the classification and discrimination of bovine, porcine and fish gelatins. Food Chemistry 190: 1109-1115.

Hashim, D.M., Che Man, Y.B., Norakasha, R., Shuhaimi, M., Salmah, Y. \& Syahariza, Z.A. 2010. Potential use of Fourier transform infrared spectroscopy for differentiation of bovine and porcine gelatins. Food Chemistry 118(3): 856860.

Hassan, N., Ahmad, T. \& Zain, N.M. 2018. Chemical and chemometric methods for halal authentication of gelatin: An overview. Journal of Food Science 83(12): 2903-2911.

Hermanto, S., Sumarlin, L.O. \& Fatimah, W. 2013. Differentiation of bovine and porcine gelatin based on spectroscopic and electrophoretic analysis. Journal of Food and Pharmaceutical Sciences 1(3): 68-73.

Hidaka, S. \& Liu, S.Y. 2003. Effects of gelatins on calcium phosphate precipitation: A possible application for distinguishing bovine bone gelatin from porcine skin gelatin. Journal of Food Composition and Analysis 16(4): 477-483.

Jain, S. \& Krishna, S. 1998. Autocatalytic sets and the growth of complexity in an evolutionary model. Physical Review Letters 81(25): 5684.

Jannat, B., Ghorbani, K., Shafieyan, H., Kouchaki, S., Behfar, A., Sadeghi, N., Beyramysoltan, S., Rabbani, F., Dashtifard, S. \& Sadeghi, M. 2018. Gelatin speciation using real-time PCR and analysis of mass spectrometry-based proteomics datasets. Food Control 87: 79-87.

Laemmli, U.K. 1970. Cleavage of structural proteins during assembly of the headbacteriophage T4. Nature 227: 680-685.

Müllertz, A., Perrie, Y. \& Rades, T. 2016. Analytical Techniques in The Pharmaceutical Sciences. New York: Springer.

Muyonga, J.H., Cole, C.G.B. \& Duodu, K.G. 2004. Fourier transform infrared (FTIR) spectroscopic study of acid soluble collagen and gelatin from skins and bones of young and adult Nile perch (Lates niloticus). Food Chemistry 86(3): 325-332.

Nemati, M., Oveisi, M.R., Abdollahi, H. \& Sabzevari, O. 2004. Differentiation of bovine and porcine gelatins using principal component analysis. Journal of Pharmaceutical and Biomedical Analysis 34(3): 485-492.

Tuah, Y. 2019. Meeting demands of the halal industry. https:// www.theborneopost.com/2019/03/03/meeting-demands-ofthe-halal-industry. Accessed on 3 September 2019.

Prager, G. 2018. Practical Pharmaceutical Engineering. New Jersey: John Wiley \& Sons.

Venien, A. \& Levieux, D. 2005. Differentiation of bovine from porcine gelatines using polyclonal anti-peptide antibodies in indirect and competitive indirect ELISA. Journal of Pharmaceutical and Biomedical Analysis 39(3): 418-424.

Widyaninggar, A., Triyana, K. \& Rohman, A. 2012. Differentiation between porcine and bovine gelatin in capsule shells based on amino acid profiles and principal component analysis. Indonesian Journal of Pharmacy 23(2): 104-109.

Nurfarhana Hassan \& Tahir Ahmad*

Department of Mathematical Sciences

Faculty of Science

Universiti Teknologi Malaysia

81310 Skudai, Johor Darul Takzim

Malaysia

Tahir Ahmad*

Department of Mathematical Science

Faculty of Science

Universiti Teknologi Malaysia

81310 Skudai, Johor Darul Takzim

Malaysia

Norhidayu M. Zain

Islamic Civilization Academy

Faculty of Social Sciences and Humanities

Universiti Teknologi Malaysia

81310 Skudai, Johor Darul Takzim

Malaysia

Azmirul Ashaari

Azman Hashim International Business School

Universiti Teknologi Malaysia

81310 Skudai, Johor Darul Takzim

Malaysia

*Corresponding author; email: tahir@ibnusina.utm.my

Received: 26 January 2020

Accepted: 22 March 2020 